\title{
Effective Adsorption of Doxorubicin Hydrochloride on the Green Targeted Nanocomposite
}

\author{
Omid Arjmand, ${ }^{1}$ Mehdi Ardjmand, ${ }^{1, \star}$ Ali Mohammad Amani ${ }^{2}$ \\ and Mohmmad Hasan Eikani ${ }^{3}$ \\ ${ }^{1}$ Department of Chemical Engineering, South Tehran Branch, Islamic Azad University, Tehran, Iran. \\ ${ }^{2}$ Department of Medical Nanotechnology, School of Advanced Medical Sciences and Technologies, \\ Shiraz University of Medical Sciences, Shiraz, Iran. \\ ${ }^{3}$ Department of Chemical Technologies, Iranian Research organization of Science and Technology (IROST), \\ P.O. Box 33535111, Tehran, Iran. \\ *Corresponding author: E-mail: m_arjmand@azad.ac.ir
}

Received: 08-22-2019

\begin{abstract}
This study examined the adsorption properties of the doxorubicin anticancer drug on a designed and fabricated system. A novel nanocomposite based on green magnetic - Graphene Oxide - Chitosan - Allium Sativum - Quercus was successfully fabricated. To evaluate the doxorubicin adsorption, the effectiveness parameters on the adsorption process were investigated including the contact time, $\mathrm{pH}$ value, concentration, the adsorbent dosage, and temperature. The results indicated that the maximum adsorption of doxorubicin on the fabricated nanocomposite occurred at $\mathrm{pH} 6.3$, concentration $3.6 \mathrm{mg} / 1.8 \mathrm{ml}$, contact time 10 minutes, and the adsorbent dosage $1.4 \mathrm{~g} / \mathrm{L}$. This designed system not only increased the drug adsorption up to $100 \%$, but it also can absorb low concentrations of doxorubicin. This suggests that the current challenge in using the higher concentrations of doxorubicin could be essentially minimized thanks to the excellent components used in the nanocomposite structure. The developed system has greatly improved DOX adsorption, confirming that the fabricated nanocomposite could be applied for a drug delivery.
\end{abstract}

Keywords: Adsorption, Doxorubicin, Nanocomposite, Natural Components, Functional Groups

\section{Introduction}

Graphene oxide $(\mathrm{GO})$ with various functional groups including hydroxyl, epoxy, and carboxyl is gaining popularity in different areas such as chemistry, materials, physics, and medicine. ${ }^{1}$ Modified GO has been explored via covalent or non-covalent bands as a desired carrier for targeted drug delivery. ${ }^{2}$ As hydrophobic drugs can be loaded on graphene sheets by $\pi-\pi$ starching, so nanocomposite design based on graphene for targeted drug delivery have been explored. ${ }^{3}$ Doxorubicin ( DOX ) as a strong anticancer agent belongs to the Adriamycin (ADM) groups which is widely utilized in the free form or combined with other drugs for cancer treatment. During the DOX injection the normal cells are also damaged and the unwanted serious side effects such as myelotoxicity and the cumulative cardiotoxicity limits its therapeutic index. Nanoparticle drug delivery system (NDDS) has attracted great attention by binding a functional ligand to reduce the side effects on normal organs. ${ }^{4}$ To reach the best therapeutic outcomes, several nanoparticles in combination with DOX have been designed to overcome this challenge. An electrostatic interaction between the positively charged amine moiety of DOX and the negatively charged of nanoparticles facilitates the DOX adsorption on the surface. ${ }^{5}$ During a reversible process on the carbon nanotube (CNT), the adsorbed and encapsulated DOX in the inner space CNT can easily cross through the cell membrane. ${ }^{6}$ The molecular interaction between the carboxylate groups and amino groups of the adjoined DOX with $\mathrm{Fe}_{3} \mathrm{O}_{4} @ \mathrm{SiO}_{2}$-Glu cause DOX to be strongly adsorbed via the chemisorptions process without any degradation. ${ }^{7}$ The molecular dynamics (MD) simulation of the adsorbed doxorubicin (DOX) drug on covalent functionalized carbon nanotubes (CNTs) revealed that the molecular interactions of DOX with $\mathrm{f}-\mathrm{CNTs}$ can provide the drug release as well. ${ }^{8}$ The release kinetics of DOX load- 
ed on mesoporous silica nanoparticle and the desired dosage of the active ingredient is associated with the initial drug adsorption and affects the extent of the adsorbed ingredien. ${ }^{9}$ Protein competition, lower $\mathrm{pH}$ values, and the short adsorption time significantly facilitate doxorubicin desorption on oxidized carbon nanotubes. ${ }^{10}$ As reported in the literature the electrostatic interactions between the negatively charged nanoferrite surface and the positively charged DOX molecules, leaded to an enhanced and effective adsorption of the drug. ${ }^{11}$ The adsorption rate of DOX on poly (methyl methacrylate) - chitosan-heparin-coated with the activated carbon was significantly reduced with an increase in the loaded heparin content. ${ }^{12}$ In this study, to illustrate the mechanism of interaction between DOX molecules and a designed biocompatible nanocomposite, adsorption analysis has been studied. The adsorption of doxorubicin, as a strong anticancer agent on the carrier surface, plays an important role in targeted treatment. Hence, a novel system based on the strong and more effective components is absolutely necessary for the drug adsorption. A novel targeted composite was designed and fabricated based on various functional groups used in its structure for further adsorption of DOX. The literature has not reported DOX adsorption on a nanocomposite based on chitosan and the natural components. The more effective functional groups existing at the natural component of allium sativum such as the hydroxyl, amino, and carboxyl groups be effectively interacted with amino group and the phenolic structure of DOX. Allium sativum used at the nanocomposite structure owing to its much effective components such as polyphones is leaded that the further functional groups of $\mathrm{OH}$ be formed and the surface charge of nanocomposite be essentially promoted, resulting the positively charged surface of the DOX molecule to be rapidly adsorbed on the fabricated nanocomposite. Indeed, the more effective functional groups existing at natural component of allium sativum and quercus such as the hydroxyl, amino, and carboxyl groups is effectively interacted with the phenol structure and aromatic ring of the DOX molecule. Chitosan as a natural polymer play an important role at the nanocomposite structure and it can help to adjoined all nonocomposite components effectively; therefore it acts as cross linker especially in the solution while the phenol group of DOX could be adsorbed onto the gel like-structure of chitosan. In addition, due to the physicochemical characterization of tumor tissue and existing of the polysaccharide receptors, chitosan will increase the cellular adsorption and further amount of the loaded drug could be released at the targeted sites. The polyphenolic molecules of the natural component as one of the most important targeted ligands could blind with amino group of the DOX molecule, resulting the drug adsorption on the designed nanocomposite be increased. Amino group of chitosan with the negative charge interact with the negative active functional groups. Taking it on consideration and investigation of the research works in literature this novel system due to the used superior components could absorb further concentration of DOX.

\section{Experimental Section}

\section{1. Chemical \& Reagents}

Iron (III) chloride hexahydrate, iron(II) chloride tetrahydrate (99\%), natural graphite flakes with average particle size of $150 \mu \mathrm{m}$ and purity of $>98 \%$, doxorubicin hydrochloride, hydrogen peroxide $\left(\mathrm{H}_{2} \mathrm{O}_{2}\right)$, potassium permanganate $\left(\mathrm{KMNO}_{4}\right)$, phosphoric acid $\left(\mathrm{H}_{3} \mathrm{PO}_{4}\right), \mathrm{FeCl}_{3}$ $6 \mathrm{H}_{2} \mathrm{O}, \mathrm{FeSO}_{4} 7 \mathrm{H}_{2} \mathrm{O}$, phosphate buffer solution (PBS), ammonia $\left(\mathrm{NH}_{3}\right)$, acid clohidric $(\mathrm{HCl})$, hydroxide sodium $(\mathrm{NaOH}), \mathrm{n}$-hexane, chitosan. The all chemical components used at this research were purchased from the Sigma-Aldrich Company.

\section{2. Natural Components}

Allium sativum from Hamadan province in western Iran, Quercus brantii and Alhagi maurorum from Fars province in southwestern Iran were obtained as natural components.

\section{3. Methodology}

To evaluate and determine the DOX adsorption on the fabricated nanocomposite, the batch experiments at different temperature, $\mathrm{pH}$, dosage, contact time, and the concentration of DOX were conducted. The $\mathrm{pH}$ value of the samples was adjusted using the diluted solutions of $\mathrm{NaOH}$ and $\mathrm{HCl}(0.1 \mathrm{M})$. In order to evaluate the adsorbed amounts of the DOX drug, the related experiments were accomplished at ranges from 190 to $800 \mathrm{~nm}$ by ultraviolet visible (UV-Vis) absorption spectrometer (Agilent technologies Cary Series UV/VIS Spectrometer model). For this case, the related experiments were conducted under the batch condition by dispersing the fabricated nanocomposite in $25 \mathrm{ml}$ solution containing the DOX drug at various conditions such as alteration of temperature, $\mathrm{pH}$, the nanocomposite dosage and the drug concentration. Subsequently, the prepared solution including the determined concentration of DOX and nanocomposite was sonicated as well at speed $4500 \mathrm{rpm}$ for 5 minutes.

\section{4. Synthesis of Graphene Oxide (GO)}

The modified Hummers method was used to synthesize the GO nanosheets as reported in the literature. ${ }^{13,14}$

\section{5. Preparation of Alhagi Maurorum Essential Oil}

The essential oil of Alhagi Maurorum using the clevenger apparatus was extracted according to the literature. ${ }^{14,15}$ 


\section{6. Preparation of Allium Sativum and Quercus Powder}

Allium sativum species belong to Hamadan province located in the west of Iran was prepared. It is peeled, chopped and washed with the deionized water and then allowed to be dried in the oven $\left(50{ }^{\circ} \mathrm{C}\right)$ for $24 \mathrm{~h}$. The dried allium sativum particles was crushed and mixed in a ball mill for $24 \mathrm{~h}$ and the prepared powder stored at $4{ }^{\circ} \mathrm{C}$. Quercus (oak) powder was also prepared according to mentioned approach. ${ }^{14}$

\section{7. Preparation of Green Magnetic/ Graphene Oxide / Chitosan / Allium Sativum / Quercus Nanocomposite}

The green magnetic - graphene oxide (GO) - chitosan (CS) - allium sativum - quercus nanocomposite was successfully fabricated as reported in the literature. ${ }^{14,16}$

\section{Results and Discussion}

\section{1. Analysis of the Adsorption and Observations}

To better understand the interaction mechanism between the DOX molecular and the fabricated nanocomposite, the surface adsorption analysis was performed. The adsorption peak of drug on the nanocomposite surface at wavelengths 290 and $482 \mathrm{~nm}$ as $\lambda$ max value was shaped.

\section{2. Characterization}

The functional groups and the surface morphology of the fabricated nanocomposite were analyzed by FTIR and SEM techniques, respectively and reported in our previous work. ${ }^{14}$

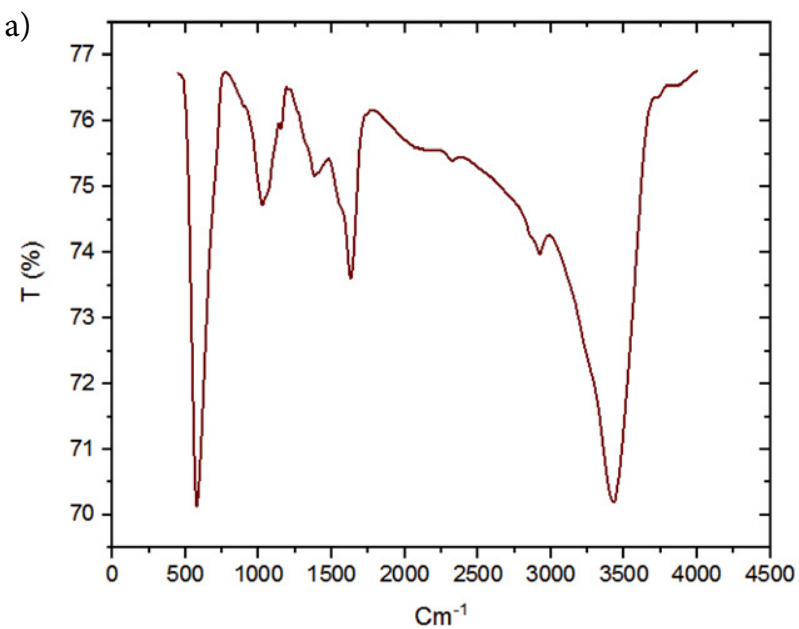

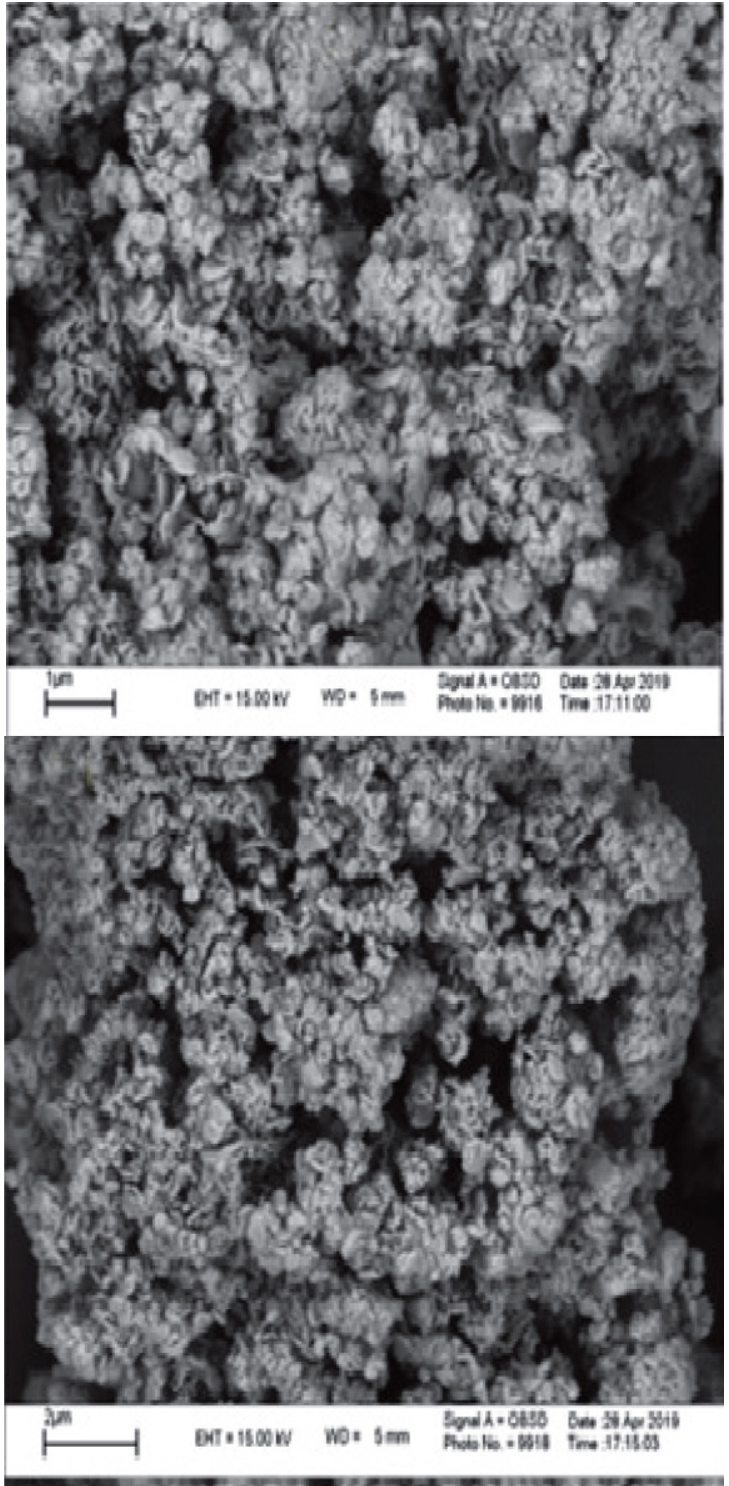

Figure 2. SEM image of fabricated nanocomposite

b)

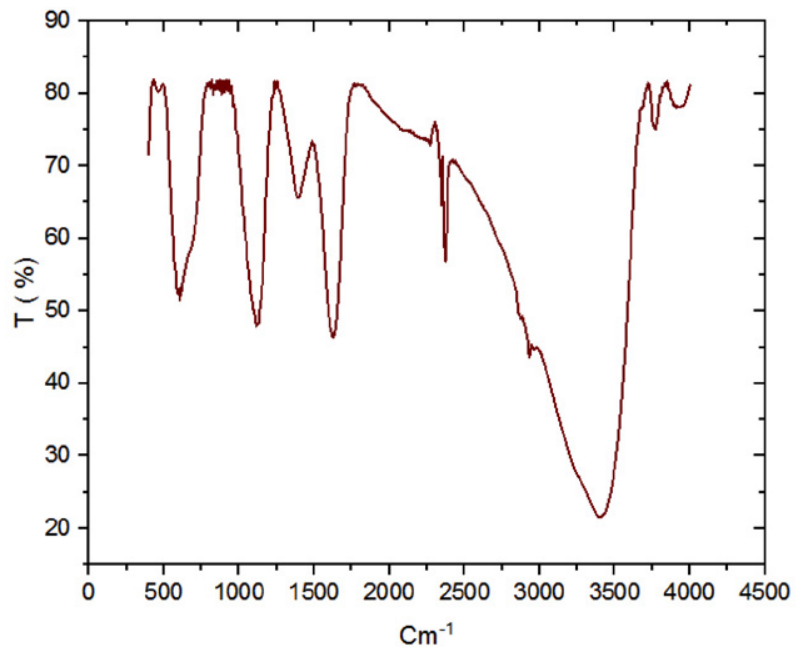

Figure 1. Fourier transform infrared spectroscopy (FTIR) spectra of a ( Mn / GO / CS/ A. sativum / Que ) b (GrMn / GO / CS / A. sativum / Que) 
The surface morphology of the designed nanocomposite was analyzed by scanning electronic microscopy (SEM). SEM image shows a high density surface with the active sites, revealing that the magnetic chitosan particles and natural components have been assembled on the GO layers (Figure 2). The observed roughness on the agglomerated and compacted regions is associated with magnetic iron oxide particles. As it can be seen, the GO layers have been basically covered with the uniform coverage of particles leading that leaded to the development of the spherical spiral structure. ${ }^{14}$ The combination and interactions between the chitosan active sites and the functional groups of the natural ingredients in the nanocomposite structure resulted in the formation of the non-uniform pores at the nanocomposite bulk and also further liquid phase accumulation occurred in the pores created between the active sites on the nanocomposite surface. Moreover, it is observed that the accumulated particles have been formed due to the strong interaction between CS and the natural ingredients used on the chemically improved GO surface. The observed multilayer structure has been formed from the combination of non-uniform porous cavity and the stacked and agglomerated particles resulting in creation of more active sites.

\section{3. Effect of $\mathrm{pH}$}

As the $\mathrm{pH}$ of the aqueous solution impacts on both surface charge and ionization degree of the adsorbent, $\mathrm{pH}$ of the supernatant and its effect as key parameter at adsorption process using the stock concentration $3.6 \mathrm{mg} / 1.8$ $\mathrm{ml}$ of DOX was analyzed and investigated. Figures 3 and 4 display the $\mathrm{pH}$ effect of initial solution on the adsorbed doxorubicin. As seen in Figure 3, the adsorption maximum was observed at $\mathrm{pH} 6.3$ for green magnetic - graphene oxide - chitosan - allium sativum - oak (quercus) (Gr Mn - GO - CS - A. sativum - Que) nanocomposite and by increasing the initial $\mathrm{pH}$ from 2.87 to 6.3 , the adsorption capacity was increased and the maximum amount of adsorption was observed at $\mathrm{pH}$ 6.3. As observed, the drug adsorption in the $\mathrm{pH}$ value above 6.3 is reduced, which may be attributed to the surface charge alteration and the formed bounds related to the functional groups. Regarding the colure alteration of DOX in the $\mathrm{pH}$ above 8.5 the adsorption capacity decreased basically, so can be concluded that at this range the DOX drug has strongly reacted with the nanocomposite. As observed for magnetic graphene oxide - chitosan - allium sativum quercus nanocomposite without using the more effective component of the alhagi maurorum, the $\mathrm{pH}$ alterations has less effect on the adsorption and the adsorption maximum was seen at the higher acidity of solution, while chemically improved Gr Mn-GO-CS- A. sativum, Que nanocomposite because of the alhagi maurorum essential oil used at nanocomposite structure created the more effective functional groups with further negatively-charged and it depends basically on $\mathrm{pH}$. It has not been reported the adsorption process of DOX on GO-CS and nanocomposite based on them, but reportedly ${ }^{17}$ that the maximum of DOX adsorption on graphene oxide take place at $\mathrm{pH}=8.5$, considering that the DOX stability by increasing $\mathrm{pH}$ decreases, consequently the made nanocomposite for the DOX adsorption is very suitable and in comparison with GO the adsorbed drug can be better released. ${ }^{18}$ The adsorbed DOX on glutaric anhydride functionalized $\mathrm{Fe}_{3} \mathrm{O}_{4} @ \mathrm{SiO}_{2}$ magnetic nanoparticles at acidity condition is much less than the fabricated nanocomposite. ${ }^{7}$

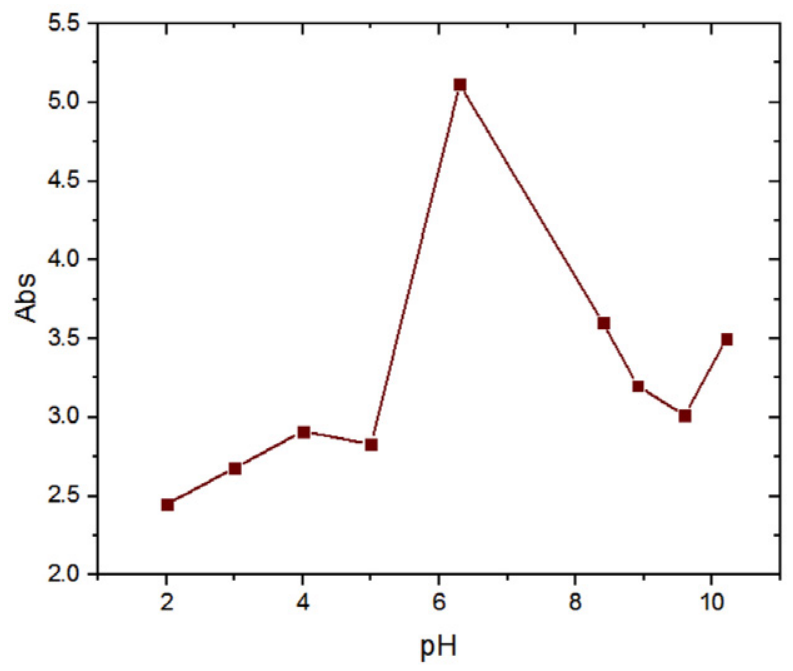

Figure 3. Effect of $\mathrm{pH}$ alterations of ( Gr Mn / GO / CS / A. sativum / Que) on drug adsorption

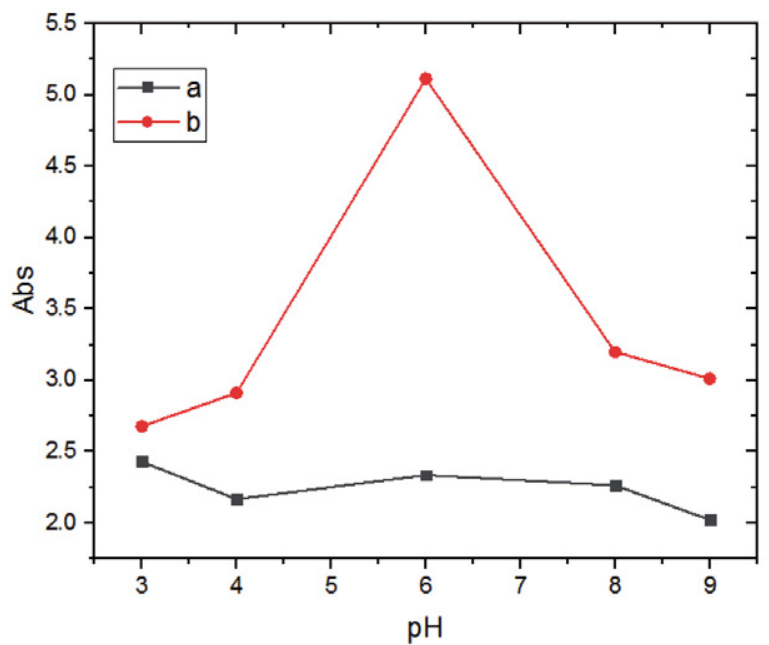

Figure 4. Effect of $\mathrm{pH}$ on the drug adsorption a ( Gr Mn / GO / CS / A. sativum / Que), b ( Mn / GO / CS / A. sativum / Que)

\section{4. Effect of Contact Time}

The contact time effect of the DOX drug on the made nanocomposite surface at concentration $3.6 \mathrm{mg} / 1.8 \mathrm{ml}$, pH 6.3 and temperature $298{ }^{\circ} \mathrm{K}$ was studied. As seen in 
Figure 5, the adsorption process takes place rapidly and after 20 minutes the adsorption capacity reaches its equilibrium state. Meanwhile, the maximum amount of adsorption after 10 minutes of the contact time was observed. The achieved results showed that by increasing the contact time up to 10 minutes, the maximum drug adsorption took place on the nanocomposite surface. Therefore, 10 minutes of the stirring time was considered as the optimal mixing time. After 10 minutes by increasing the contact time, adsorption become constant and after 20 minutes be gradually decreased which may be due to a decrease of the active sites and the driving force. Further, after 5 minutes of mixing the adsorption peak at the lower wavelength 290 $\mathrm{nm}$ shies to $300 \mathrm{~nm}$ and the higher peak of adsorption $(482 \mathrm{~nm})$ is prolonged to $300 \mathrm{~nm}$. This designed system in comparison with GO / vitamin C with 24 h of contact time has very higher potential for DOX adsorption. ${ }^{19}$

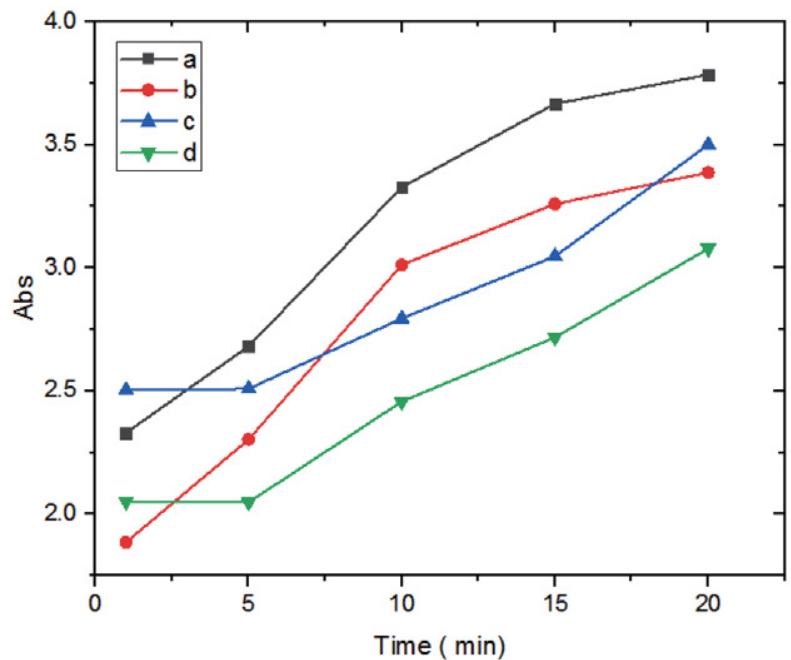

Figure 5. The effect of contact time on drug adsorption a, (Dosage $=1.6 \mathrm{gr} / \mathrm{L}, \lambda \max =482) \mathrm{b}($ Dosage $=1.6 \mathrm{gr} / \mathrm{L}, \lambda \max =290) \mathrm{c}$ (Dosage $=0.8 \mathrm{gr} / \mathrm{L}, \lambda \max =482) \mathrm{d}($ Dosage $=0.8 \mathrm{gr} / \mathrm{L}, \lambda \max =$ 290)

\section{5. Effect of Nanocomposite Dosage}

The effect of nanocomposite dosage on the DOX adsorption at $\mathrm{pH}$ 6.3, was investigated. As observed from Figure 6, by increasing the nanocomposite amount from $0.8 \mathrm{gr} / \mathrm{L}$ to $1.6 \mathrm{gr} / \mathrm{L}$, the drug adsorption has essentially increased and at $1.6 \mathrm{gr} / \mathrm{L}$ the DOX adsorption reached its maximum amount. As expected, by increasing the nanocomposite dosage due to the more availability of the active sites, the drug adsorption be increased. With further increase at nanocomposite dosage from $2 \mathrm{gr} / \mathrm{L}$ to $2.4 \mathrm{gr} / \mathrm{L}$ the adsorption capacity has been significantly increased. Indeed, increase of the drug adsorption at this range is due to the saturated concentration of nanocomposite and instability of the aqueous solution at the higher dosage from $2 \mathrm{gr} / \mathrm{L}$. The optimum dosage for the DOX adsorption was $1.4 \mathrm{gr} / \mathrm{L}$ and the adsorption capacity reached the maxi- mum taking in to consideration all conditions. Indeed, with alteration of the other parameters such as the contact time, the drug adsorption could be increased. Considering the dosages used, the optimum dosage $1.4 \mathrm{gr} / \mathrm{L}$ was found and selected. The effect of the CS, GO-CS amount as the adsorbent on the drug adsorption was also investigated and they were compared to the used nanocomposite. As illustrated in Figure 7, the made nanocomposite toward CS, GO-CS has the higher adsorption capacity and in comparison with CS, GO-CS has increased the DOX adsorption around $40 \%, 20 \%$, respectively. Regarding the used CS, GO at the nanocomposite structure, it is indicated that the natural components such as allium sativum, quercus, alhagi maurorum chemically have improved the designed system and their much effective molecules such as polyphones is leaded that the drug adsorption be significantly increased.

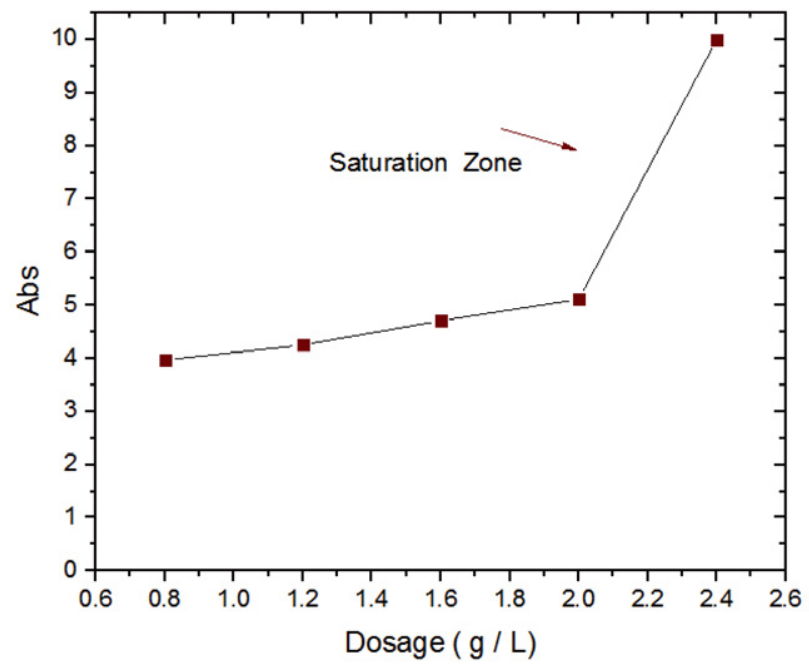

Figure 6. Effect of used dosage of nanocomposite on the DOX adsorption

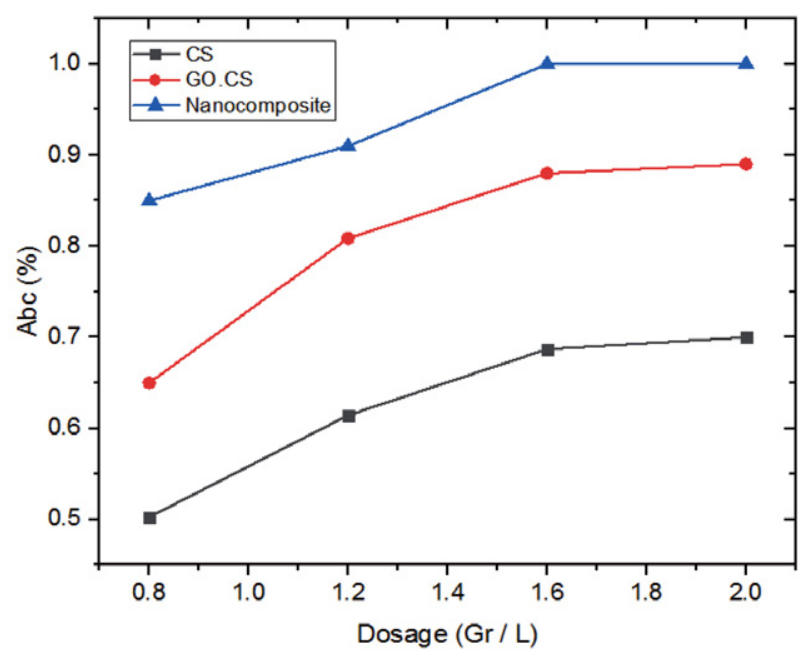

Figure 7. The effect of the used CS, GO-CS, fabricated nanocomposite adsorbent on the DOX adsorption 


\section{6. Effect of Drug Concentration}

The effect of drug concentration on the adsorption efficiency with various concentrations at $\mathrm{pH} 6.3$ for $\mathrm{Gr} \mathrm{Mn}$ - GO - CS - A. sativum - Que nanocomposite was investigated. As shown from Figure 8, with increase in the drug concentration, the amount of the drug adsorption increased. By increasing the drug concentration further molecules of drug are contacted to the nanocomposite surface, resulting the amount of DOX adsorption be essentially increased. At $\mathrm{pH} 6.3$ and temperature $298^{\circ} \mathrm{k}$, the maximum of adsorption at concentration $3.6 \mathrm{mg} / 1.8 \mathrm{ml}$ was observed. Designed and fabricated nanocomposite with the superior properties can absorb further concentrations of drug and reduce the side effects of the used drug at high concentration. The results were compared with the fabricated nanocomposite without the green alhagi maurorum essential oil, (Mn - GO - CS - A. sativum - Que)

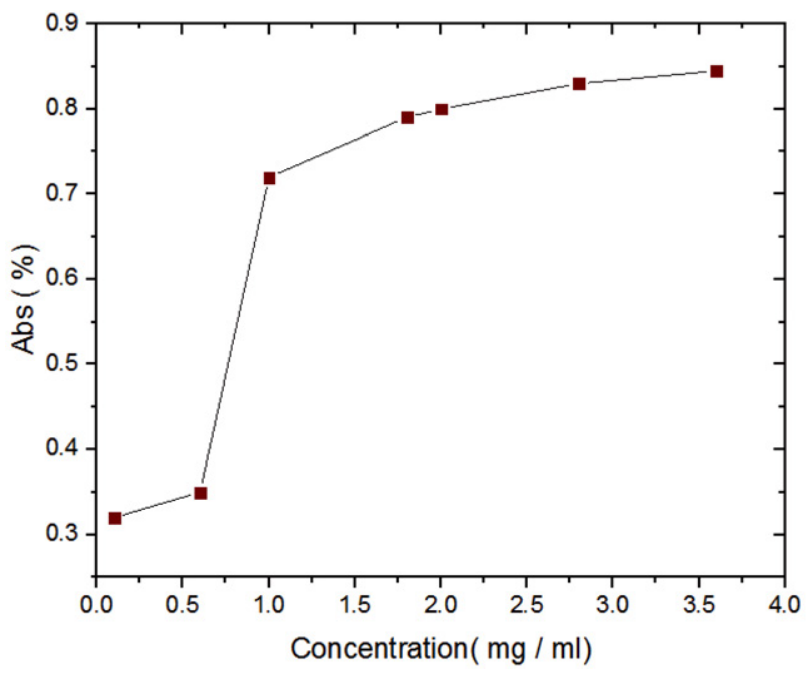

Figure 8. The effect of DOX concentration on adsorption efficiency of Gr Mn / GO / CS / A. sativum / Que

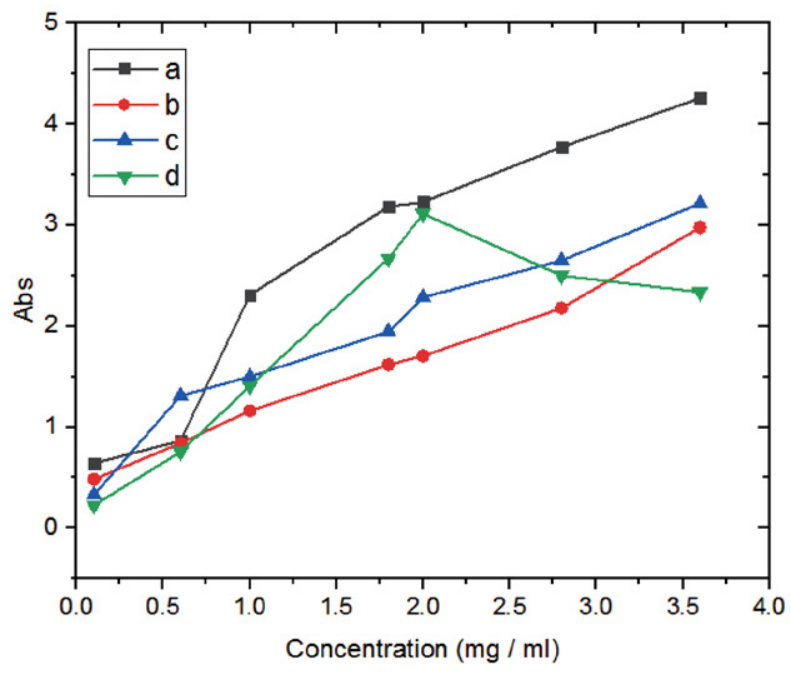

Figure 9. The DOX adsorption at different concentrations using, a (Gr Mn / GO / CS / A. sativum / Que) b ( Free DOX ) C (Mn CS) $\mathrm{d}$ ( $\mathrm{Mn} / \mathrm{GO} / \mathrm{CS} / \mathrm{A}$. sativum / Que) nanocomposite and free DOX. The calibration cure related to DOX at wavelength $490 \mathrm{~nm}$ was drawn and the second peak was observed at $294 \mathrm{~nm}$. The results indicated that by increasing the DOX concentration from its initial concentration the adsorption capacity at dosage $0.8 \mathrm{gr} / \mathrm{L}$ reaches $85 \%$ and at higher dosage of drug adsorption reaches $100 \%$. Compared to the magnesium oxide nanoparticles, graphene oxide, this nanocomposite could adsorb further concentrations of DOX. ${ }^{20,16}$

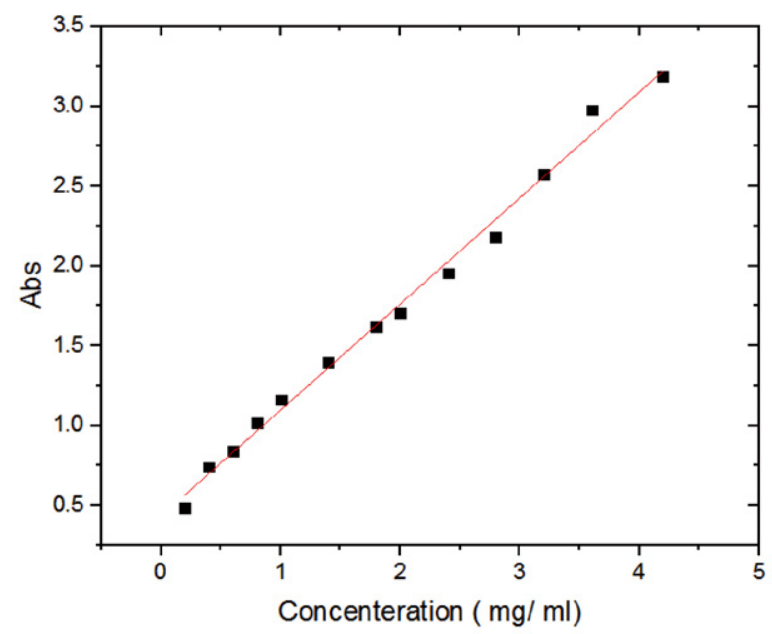

Figure 10. The calibration carve of DOX adsorption

\section{7. Effect of Temperature on the Drug Adsorption}

The drug adsorption on the made nanocomposite at the various temperatures was evaluated. The obtained results demonstrated that increasing the temperature to more than $30^{\circ} \mathrm{C}$ decreased the drug adsorption basically and at this range the drug adsorption is rapidly destroyed. At temperature $30^{\circ} \mathrm{C}$, the drug adsorption was suddenly increased that resulting of further molecular motion and

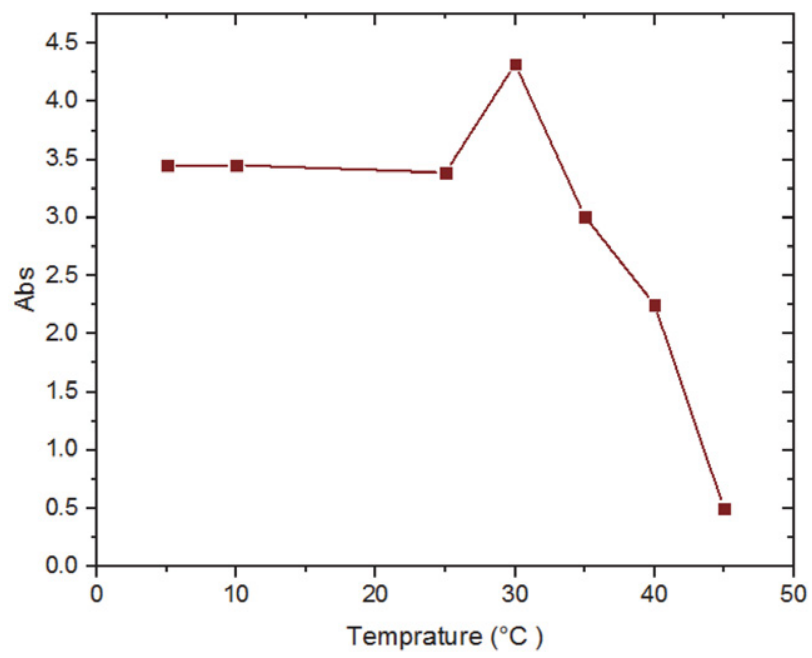

Figure 11. Effect of temperature on drug adsorption 
high competitiveness to the occupied active sites on the nanocomposite surface. At lower temperatures the adsorbed drug has high stability and affective drug loading at this range must be considered.

\section{8. Absorption Isotherm}

The adsorption isotherms study describes the nature of the formed adsorption and interaction pathway of adsorbate with adsorbents. Somehow monolayer sorption process onto the adsorbent surface with a finite number of the uniform adsorption sites without transmigration of adsorbate and adsorption on the heterogeneous surface are associated with Langmuir and Freundlich models respectively. Thus, as illustrated in Figure 12, the obtained results using Langmuir and Freundlich models were modeled for better understanding of the adsorption process.

$$
\begin{array}{ll}
\frac{c_{e}}{q_{e}}=\frac{1}{b q_{\max }}+\frac{c_{e}}{q_{\max }} & \text { Langmuir equation: } \\
\ln q_{e}=\ln k_{f}+\frac{1}{n} \ln c_{e} & \text { Freundlich equation: }
\end{array}
$$

For Freundlich isotherm $\mathrm{q}_{\mathrm{e}}, \mathrm{C}_{\mathrm{e}}$, are concentrations of the adsorbed drug toward the adsorbent amount at the equilibrium state ( $\mathrm{mg} / \mathrm{g}$ ), equilibrium concentration ( $\mathrm{mg} /$ $\mathrm{L}$ ), as well as the model constants of $\mathrm{K}_{\mathrm{f}}$ and $\mathrm{n}$ represent the relationship between the adsorption capacity and the adsorption intensity, respectively. By plotting $\log$ qe vs. $\log \mathrm{C}_{e}$ the amounts of $\mathrm{K}_{\mathrm{f}}$ and $\mathrm{n}$ from the intercept and the slope, are determined respectively. For Langmuir model, $\mathrm{C}_{\mathrm{e}} / \mathrm{q}_{\mathrm{e}}$, $\mathrm{C}_{\mathrm{e}}$, constant $\mathrm{b}$ and $\mathrm{q}$ max as index of the adsorption specification, equilibrium concentration of adsorption, adsorption energy and the maximum adsorption capacity, are expressed respectively. Furthermore, by plotting $\left(\mathrm{C}_{\mathrm{e}} / \mathrm{q}_{\mathrm{e}}\right)$ versus the equilibrium concentration $\left(\mathrm{C}_{\mathrm{e}}\right)$, adsorption energy and the maximum adsorption capacity from Langmuir isotherm are measured. The obtained parameters associated with adsorption isotherms have been summarized in Table (1).

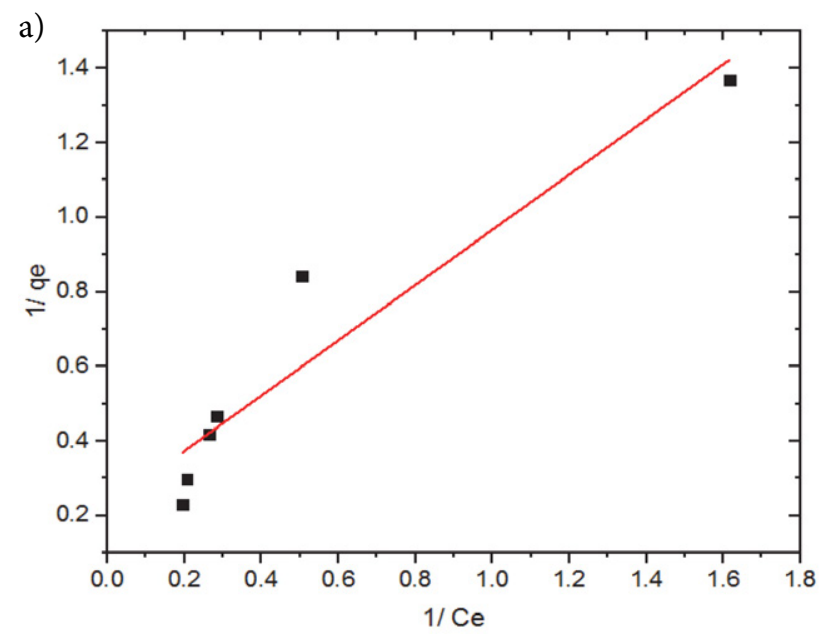

Table 1. Parameters related to the adsorption isotherm.

\begin{tabular}{lccccc}
\hline Model & Kf & $\mathbf{b}(\mathbf{L} / \mathbf{m g})$ & $\mathbf{q m}(\mathbf{m g} / \mathbf{g})$ & $\mathbf{R}^{\mathbf{2}}$ & $\mathbf{n}$ \\
\hline Langmuir & & 0.99 & 4.44 & 0.91 & \\
Freundlich & 2.13 & & & 0.96 & 0.79 \\
\hline
\end{tabular}

The results indicate that the Freundlich adsorption model according to the gained optimum conditions has the higher correlation coefficient $\left(\mathrm{R}^{2}=0.9613\right)$ and compared to the Langmuir model it can better describe DOX adsorption. As value of the correlation coefficient for both isotherm is close to unique and as it was found at low concentration of drug the Langmuir model shows appropriate behavior, revealing that the drug adsorption is monolayer, whereas at the higher concentration of drug the Freundlich isotherm better fits the experiment results consequently, it can be concluded that adsorption process follows both isotherms but according to further concentration of drug for targeted therapy is considered, indicating that the Freundlich isotherm has more advantage and better describes the drug adsorption process.

\section{9. The Kinetic Study of Adsorption}

As the kinetic study of adsorption reveals the better understanding of the took place process and considering that the speed of molecular interaction into supernatant has a potential influence on the physicochemical adsorption, therefore the mechanism of adsorption in terms of the kinetic alterations must be basically considered and investigated. Indeed, with accurate assessment of the adsorption kinetics could monitor and adjust the effective parameter, resulting that the adsorption efficiency be promoted. For current research the experimental date with four selected models was adapted and investigated. Figure13 illustrates the used kinetic models related to the experimental date of the DOX adsorption. The kinetic models are described according to following equations:

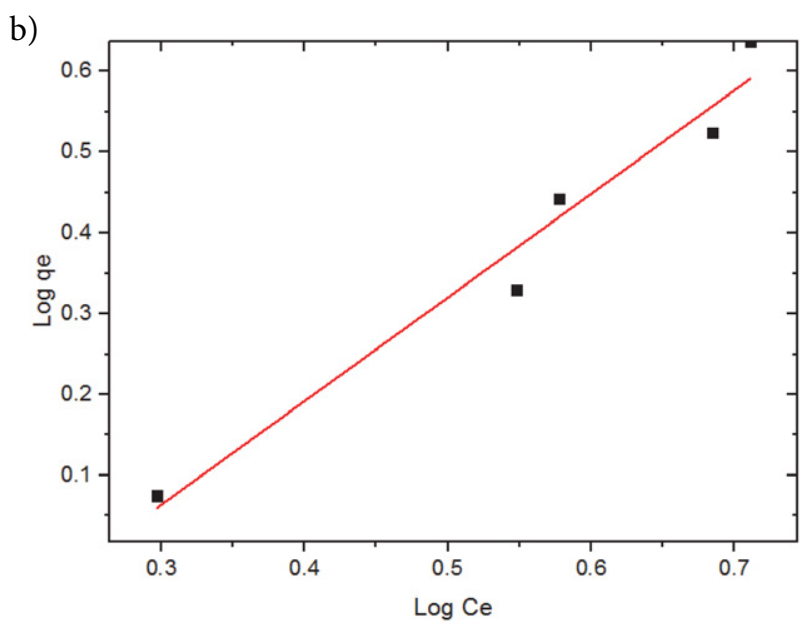

Figure 12. Langmuir curve of adsorption (a ) Freundlich curve of adsorption ( b) 


$$
\log \left(q_{e}-q_{t}\right)=\log q_{e}-k_{a d} \frac{t}{2.303}
$$

The pseudo-first-order equation

$$
\frac{t}{q_{t}}=\frac{1}{k_{2} q_{e 2}}+\frac{t}{q_{e}}
$$

The pseudo-second-order equation

$$
q_{t}=k_{i} t^{1 / 2}+C
$$

\section{The intra-particle diffusion model}

$$
q_{t}=\frac{1}{\beta} \ln \alpha \beta+\frac{1}{\beta} \ln t
$$

\section{The Elovich model}

Where $\mathrm{q}_{\mathrm{e}}$ and $\mathrm{q}_{\mathrm{t}}$, are the adsorption capacities of DOX at time $t$ and equilibrium, also $\mathrm{K}_{1}, \mathrm{~K}_{2}, \mathrm{~K}_{\mathrm{i}} \mathrm{min}^{-1}$ are the equilibrium rate constant of pseudo-second kinetic

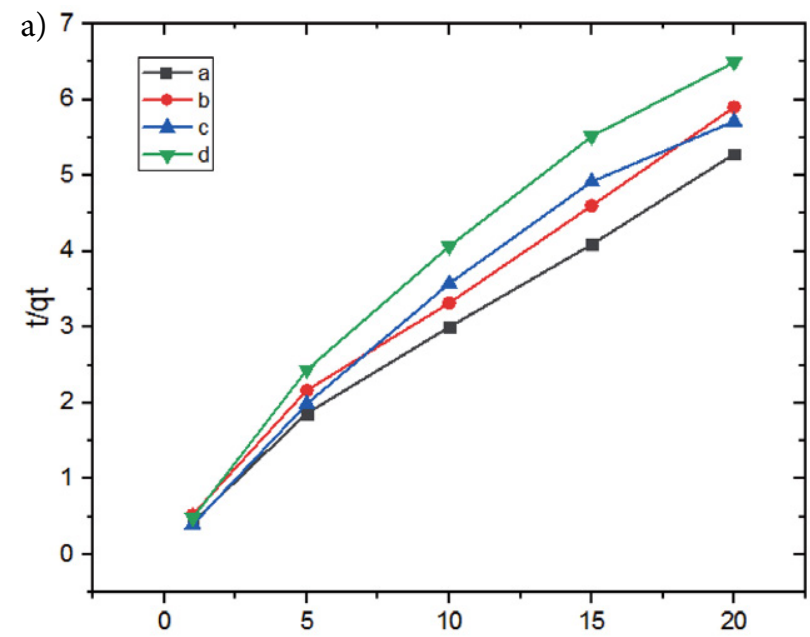

b)

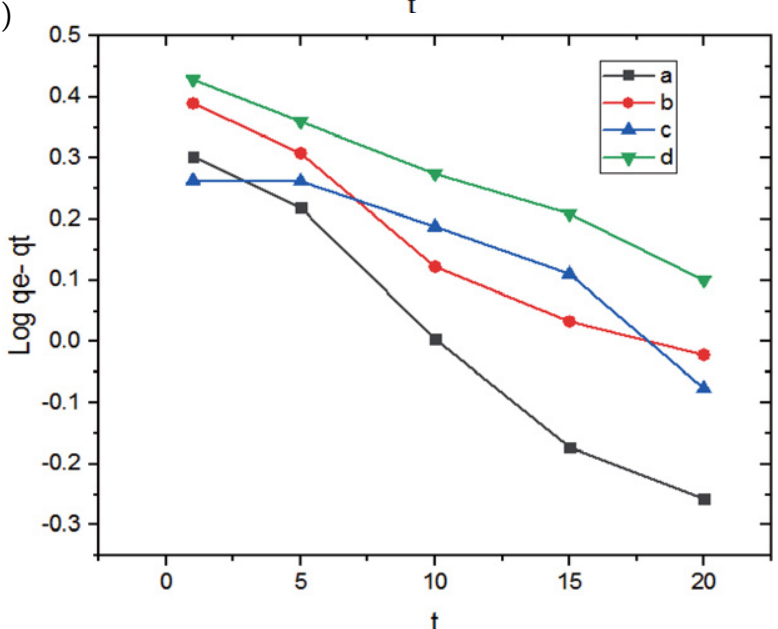

model, pseudo-first kinetic model, intra-particle diffusion (ki) at stage $i$, respectively. The constants $\alpha$ and $\beta$ by plotting qt versus $\ln t$ from the slope and intercept were determined. The kinetics parameters have been summarized at Table 2.

The kinetic studies demonstrated an enhanced drug adsorption due to the further contact of DOX molecules with the designed and fabricated system. It was also found that by increasing the contact time up to 5 minutes, the maximum adsorption wavelength from $482 \mathrm{~nm}$ shifted to $290 \mathrm{~nm}$ possibly due to the higher competitiveness between molecules in the supernatant. The experimental data fitting the kinetics models indicated that the simultaneous increase of the nanocomposite dosage and the contact time caused enhanced drug adsorption. As observed in Figure 14, the pseudo-second-order kinetic model compared to the other kinetic models used has fitted the experimental results as well, and considering the same conditions higher accordance is observed.

c)

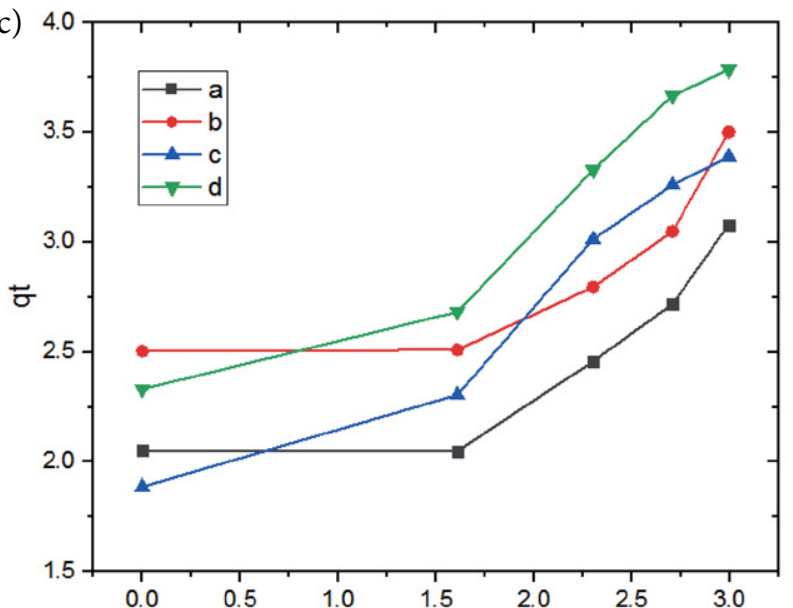

d)

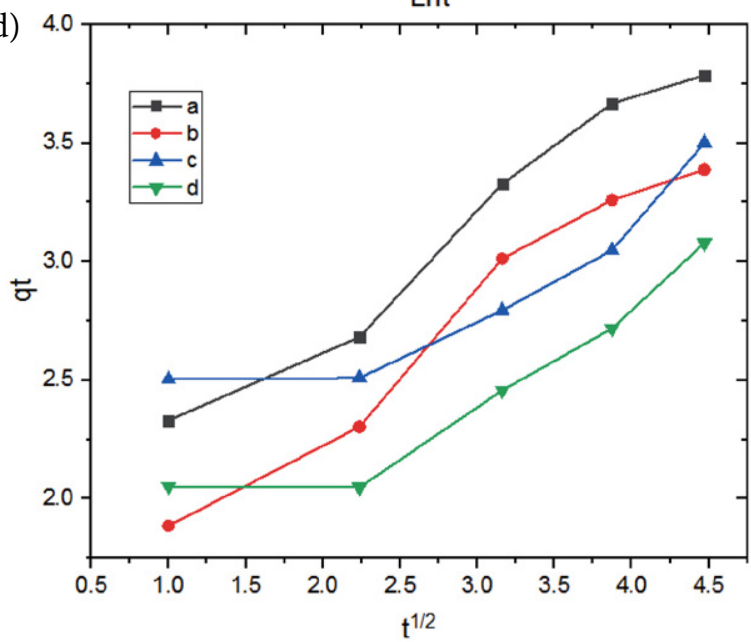

Figure 13. The kinetics models plot for DOX adsorption a (Dosage $=1.6 \mathrm{gr} / \mathrm{L}, \lambda \max =482) \mathrm{b}($ Dosage $=1.6 \mathrm{gr} / \mathrm{L}, \lambda \mathrm{max}=292) \mathrm{c}($ Dosage $=0.8 \mathrm{gr}$ $/ \mathrm{L}, \lambda \max =482) \mathrm{d}($ Dosage $=0.8 \mathrm{gr} / \mathrm{L}, \lambda \max =290) \mathrm{A}, \mathrm{B}, \mathrm{C}, \mathrm{D}$ pseudo-second kinetic model, pseudo-first kinetic model, intra-particle diffusion model, Elovich model, respectively 
a)
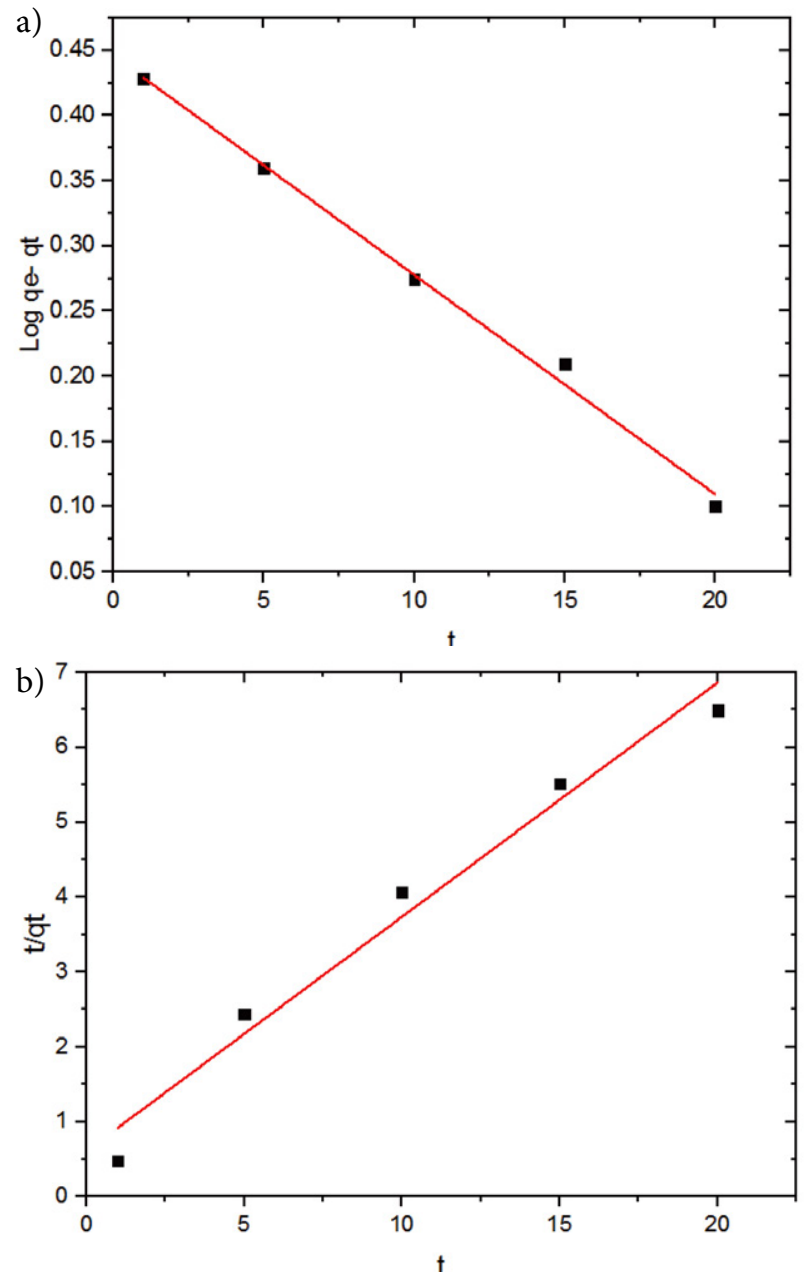

c)

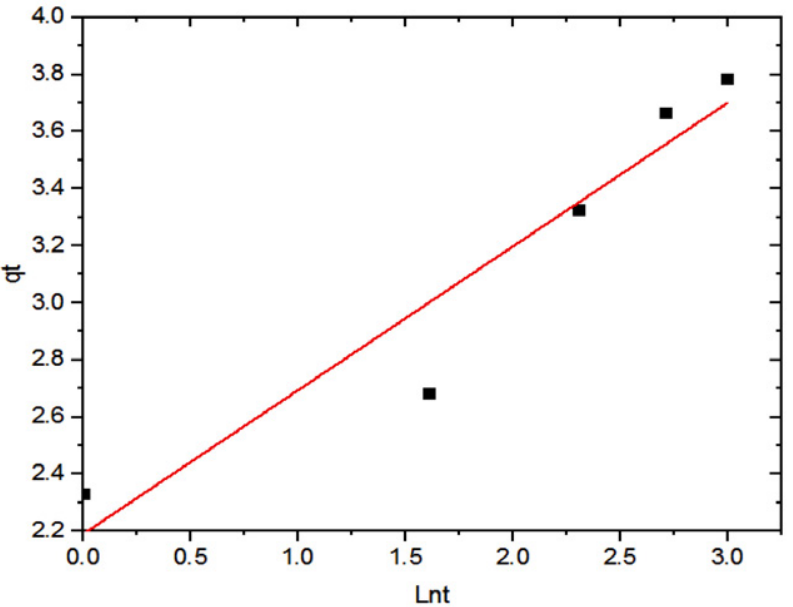

d)

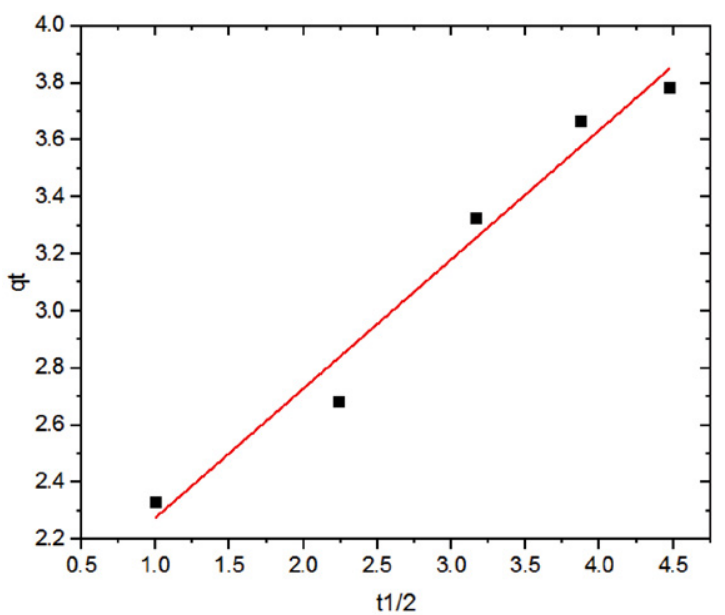

Figure 14. Kinetics analysis of the drug adsorption on fabricated nanocomposite (a) fitting by the first-second-order model (b) fitting by the pseudo-second-order model; (c) fitting by Elovich model; (d) fitting by the intraparticle diffusion model

Table 2. The kinetic parameters of adsorption

\begin{tabular}{lcccccccc}
\hline & $\mathbf{R}^{\mathbf{2}}$ & $\mathbf{q e}$ & $\mathbf{q t}$ & $\mathbf{K}_{\mathbf{1}}$ & $\mathbf{K}_{\mathbf{2}}$ & $\mathbf{K}_{\mathbf{i}}$ & $\boldsymbol{\alpha}$ & $\boldsymbol{\beta}$ \\
\hline $\begin{array}{l}\text { Pseudo-First } \\
\text { order kinetic model }\end{array}$ & 0.976 & 4.31 & 4.73 & 0.056 & & & & \\
$\begin{array}{l}\text { Pseudo-second } \\
\text { order kinetc model }\end{array}$ & 0.995 & 3.56 & 3.51 & & 0.174 & & & \\
$\begin{array}{l}\text { Intra-particle diffusion } \\
\text { Elovich model }\end{array}$ & 0.973 & & 2.028 & & & 0.5324 & & \\
\hline
\end{tabular}

\section{10. Thermodynamic of Adsorption}

The thermodynamic parameters related to the drug adsorption including the alterations of Gibbs free energy $\left(\Delta \mathrm{G}^{\circ}\right)$, enthalpy $\left(\Delta \mathrm{H}^{\circ}\right)$ and entropy $\left(\Delta \mathrm{S}^{\circ}\right)$, via the van't Hoff equation were evaluated and measured.

$$
\begin{aligned}
& K_{d}=\frac{q_{e}}{C_{e}} \\
& \Delta G^{o}=-R T \ln K_{d} \\
& \ln K_{d}=-\frac{\Delta H^{o}}{R T}+\frac{\Delta S^{o}}{R}
\end{aligned}
$$

$$
\Delta S^{o}=\frac{\Delta G^{o}-\Delta H^{o}}{T}
$$

In addition, $\Delta \mathrm{H}^{\circ}\left(\mathrm{kJ} \mathrm{mol}^{-1}\right), \Delta \mathrm{G}^{\circ}\left(\mathrm{kJ} \mathrm{mol}{ }^{-1}\right), \Delta \mathrm{S}^{\circ}(\mathrm{J}$ $\left.\mathrm{mol}^{-1} \mathrm{~K}^{-1}\right)$ as the important thermodynamic qualities, the other appeared parameter at above equation are the known universal gas constant and the absolute temperature $\left(\mathrm{K}^{\circ}\right)$. Where $\mathrm{K}_{\mathrm{d}}$ represents the ratio of the adsorbed drug on the surface of fabricated nanocomposite at equilibrium $\left(\mathrm{q}_{\mathrm{e}}\right)$ to the residual concentration of DOX drug into supernatant at equilibrium $\left(\mathrm{C}_{\mathrm{e}}\right)$. By plotting $\ln \left(\mathrm{q}_{\mathrm{e}} / \mathrm{C}_{\mathrm{e}}\right)$ vs. $\mathrm{q}_{\mathrm{e}}$ and determination of the intercept $K_{d}$ be obtained (Figure 15). 
Further, isosteric heat of adsorption according to Clausius - Clapeyron equation was calculated (Figure 16). The thermodynamic parameters of drug adsorption have been summerized in Table 3.

$$
\frac{\mathrm{d}(\operatorname{Ln} \mathrm{Ce})}{\mathrm{dT}}=\frac{\Delta \mathrm{Hx}}{\mathrm{R} T^{2}}
$$

Clausius- Clapeyron equation

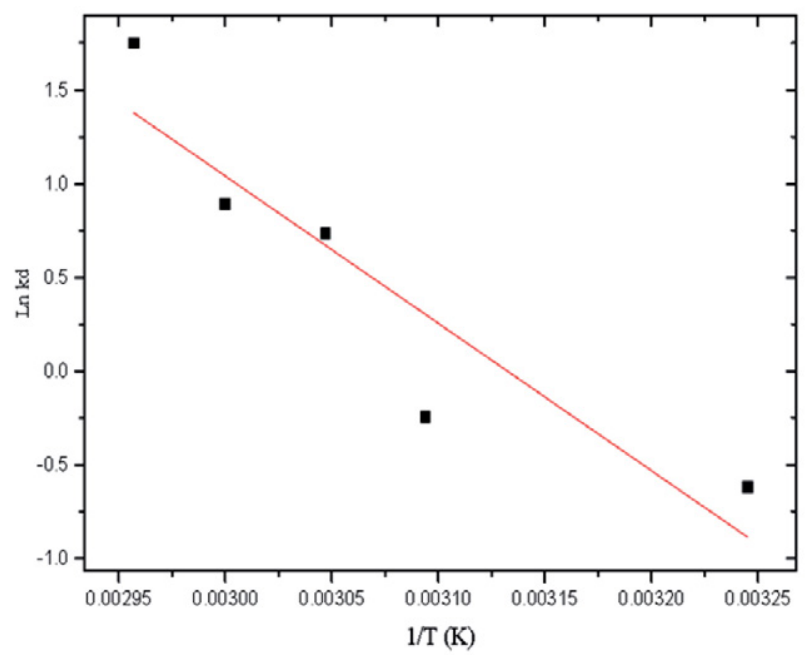

Figure 15. Ln $\mathrm{k}$ vs temperature for calculation of thermodynamic properties.

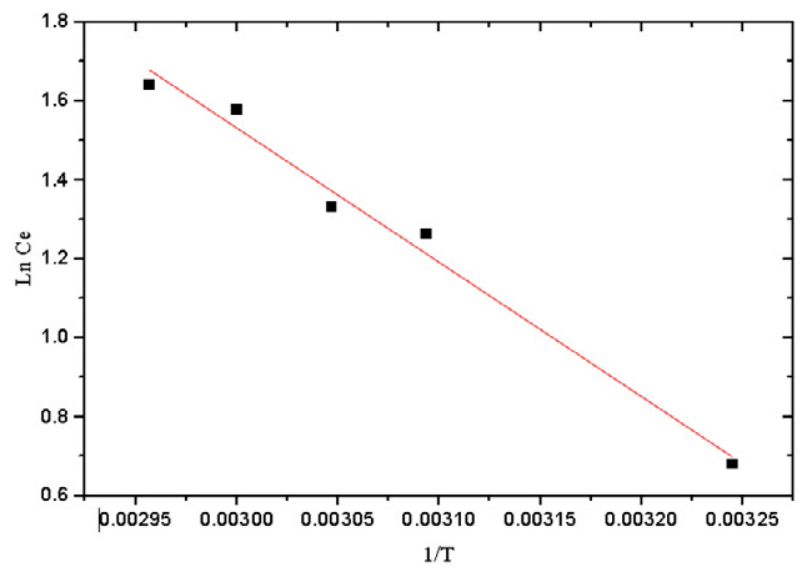

Figure 16. Ln Ce vs temperature for calculation isosteric heat of adsorption
The results indicated that at range concentration up to $1 \mathrm{mg} / \mathrm{ml}$ the surface excess has increased, while by increasing the concentration from $1 \mathrm{mg} / \mathrm{ml}$ the surface excess has basically increased. Meanwhile at concentration 3.6 it reached its minimum amount, resulting at concentration 3.6 the maximum amount of DOX has been adsorbed on the nanocomposite surface (Figure 17).

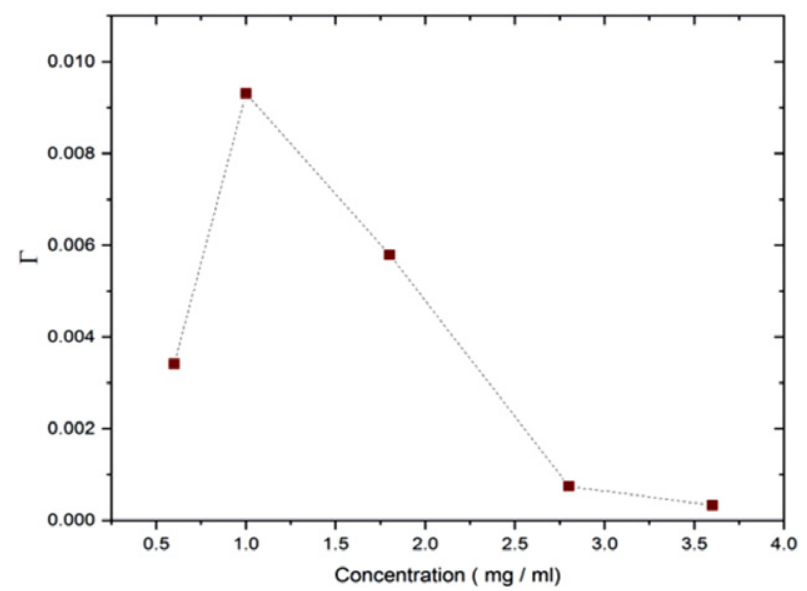

Figure 17. The alteration of surface excess with drug concentration.

\section{Conclusion}

As the physical interactions between doxorubicin and the fabricated nanocomposite plays an important role in the drug loading and release, thus by adjusting the effective parameters, the best clinical therapy state can be achieved. The obtained results revealed that by increasing the drug concentration and the nanocomposite dosage, the DOX adsorption increased. Under acidity conditions, more adsorption of DOX was observed with the maximum adsorption capacity occurring at $\mathrm{pH}$ 6.3. The drug adsorption satisfactorily followed both Langmuir and Freundlich isotherms at lower and higher concentrations of the drug, respectively. Our findings indicated that the obtained experimental data of the drug adsorption results in compression with the other kinetic model was further consisted with the pseudo-second kinetic model. The ob-

Table 3. Thermodynamic parameters of adsorption

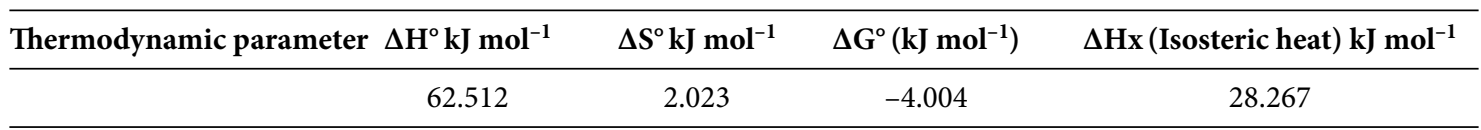

\section{11. Surface Excess}

Surface excess is defined as a concentration in a small volume near the surface nanocomposite.

$\Gamma=\frac{(C \text { initial }-C \text { after adsorption }) \cdot \text { Volume }}{\text { Surface area }}$ tained thermodynamic parameters revealed that the adsorption process of DOX on the nanocomposite surface was endothermic and spontaneous. This designed nanocomposite had a high efficiency of DOX adsorption thanks to the excellent component used in its structure; so it can essentially be considered and used in targeted drug deliv- 
ery. Indeed, since the current challenge in using higher concentrations of DOX during clinical treatment of cancer limits its efficiency, the design of an effective system with a high performance of adsorption is a necessity for medical applications. This drug system with high adsorption properties in the field of chemotherapy and targeted drug delivery could load the further amount of drug, resulting the encapsulated drug efficiency be essentially improved. Furthermore, the nanocomposite made with a unique component could act as anticancer agent.

\section{References}

1. H. Zh. Tifeng, J. E. Lexin, Zh. Jingxin. Zh. Qingrui, Zh. Email, Q. P. Xuehai Yan Sci China Mater 2015, 10, 811-818. DOI:10.1007/s40843-015-0090-x

2. J. Liu L. Cui, D. Osic Acta Biomaterialia 2013, 9, 9243-9257. DOI:10.1016/j.actbio.2013.08.016

3. Xi. Zhang, W. Cai, Li Hao, S. Feng, Qi. Lin, W. Jiang Journal of Nanomaterials 2017, 2017, 1-10. DOI:10.1155/2017/6702890

4. D. Bi, L. Zhao, R. Yu, H. Li, Yi. Guo, Xi. Wang, M. Han Drug Delivery 2018, 25, 564-575.

DOI:10.1080/10717544.2018.1440447

5. D. Curry, A. Cameron, B. MacDonald, C. Nganou, H. Scheller, J. Marsh, S. Beale, M. Lu, Zh. Shan, R. Kaliaperumal, H. $\mathrm{Xu}, \mathrm{M}$. Servos, C. Bennett, S. MacQuarrie, K. D. Oakes, M. Mkandawirea, X. Zhang Nanoscale 2015, 7, 19611-19619. DOI:10.1039/C5NR05826K

6. Sh. Sadaf, L. Walder Adv. Mater. Interfaces 2017, 4, 1-10. DOI:10.1002/admi.201700649

7. W. Caia, M. Guoa, Xi. Wenga, W. Zhangb, Zu. Chen Materials Science \& Engineering C 2019, 98, 65-73.

DOI:10.1016/j.msec.2018.12.145

8. A. Kordzadeh, S. A. -Iranagh, M. Zarif, H. Modarress Journal of Molecular Graphics and Modeling 2019, 88, 11-22.

DOI:10.1016/j.jmgm.2018.12.009
9. N. V. Roik, Lyudmila A. Belyakova, M. O. Dziazko Adsorption Science \& Technology 2016, 35, 86-101.

DOI:10.1177/0263617416669504

10. Y. Wanga, Sh. Yanga, Y. Wanga, Y. Liua, H. Wang Colloids and Surfaces B: Biointerfaces 2012, 97, 62-69.

DOI:10.1016/j.colsurfb.2012.04.013

11. K. Nawara, J. Romiszewski, K. Kijewska, J. Szczytko, A. Twardowski, M. Mazur, P. Krysinsk J. Phys. Chem. C 2012, 116, 5598-5609. DOI:10.1021/jp2095278

12. J. Miao, F. Zhang, M. Takieddin Sh. Mousa, R.J. Linhardt Langmuir 2012, 28, 4396-4403.

DOI:10.1021/la3000137

13. N. I. Zaabaa, K. L. Fooa, U. Hashima, S. J. Tanb, Wei-Wen Liua, C. H. Voon Procedia Engineering 2017, 184, 469-477. DOI:10.1016/j.proeng.2017.04.118

14 O. Arjmand, M. Ardjmand, A. M. Amani M. H. Eikani Anti-Cancer Agents in Medicinal Chemistry 2020, 20 (1). DOI:10.2174/1871520620666200213105203

15 J. F. Clevenger The Journal of the American Pharmaceutical Association 1912, 17, 345-349. DOI:10.1002/jps.3080170407

16. Y. Wei, B. Han, X. Hu, Y. Lin, X. Wang, X. Deng Procedia Engineering 2012, 27, 632-637.

DOI:10.1016/j.proeng.2011.12.498

17. B. KartickS. K. Srivastava, I. Srivastava Journal of Nanoscience and Nanotechnology 2013, 13, 4320-4324.

DOI:10.1166/jnn.2013.7461

18. Sh. Wu, X. Zhao, Y. Li, Q. Du, J. Sun, Y. Wang, X. Wang, Y. Xia, Z. Wang, L. Xia Materials 2013, 6, 2026-2042. DOI:10.3390/ma6052026

19. Z. Liu, J. Liu, T. Wang, Q. Li, P. S. Francis, C. J. Barrow, W. Duan, W.Yang J. Mater. Chem. B. 2018, 6, 1251-1259. DOI:10.1039/C7TB03063K

20. T. Somanathan1, V. M. Krishna, V. Saravanan, R. Kumar, R. Kumar, Journal of Nanoscience and Nanotechnology 2016, 16, 9421-9431. DOI:10.1166/jnn.2016.12164

\section{Povzetek}

V tej študiji smo preučevali adsorpcijo zdravila proti raku doksorubicina na ciljno načrtovan in izdelan material. Gre za nov nanokompozit pripravljen iz zelenega magneta, grafen oksida, hitozana ter česnovega in hrastovega prahu. Za ovrednotenje adsorpcije doksorubicina smo spreminjali različne parametre kot so kontaktni čas, $\mathrm{pH}$ vrednost, koncentracija, količina adsorbenta in temperatura. Rezultati so pokazali, da je adsorpcijski maksimum pripravljenega kompozita dosežen pri pH vrednosti 6.3 , koncentraciji $3.6 \mathrm{mg} / 1.8 \mathrm{ml}$, kontaktnem času $10 \mathrm{~min}$ in količini adsorbenta 1.4 g/L. Pripravljen sistem kaže preko 100 \% boljše adsorpcijske lastnosti, adsorpcija pa je učinkovita tudi pri nizkih koncentracijah. Zaradi tega so potrebne nižje količine adsorbenta, tudi pri višjih koncentracijah doksorubicina. Pripravljen kompozit torej kaže superiorne adsorpcijske lastnosti in bi ga lahko uporabili kot dostavni sistem za zdravilo.

Except when otherwise noted, articles in this journal are published under the terms and conditions of the Creative Commons Attribution 4.0 International License 